\title{
ОЩАДЛИВІСТЬ У СТРУКТУРІ ФІНАНСОВОЇ ТА ЕКОНОМІЧНОЇ ГРАМОТНОСТІ ОСОБИСТОСТІ
}

\section{Власенко Я. В.}

здобувач третього (освітньо-наукового) рівня вищої освіти кафедри освітології та інноваційної педагогіки, Харківський національний педагогічний університет імені Г. С. Сковороди, м. Харків, Україна

У статті розглянуті основні складові ощзадливості, функиї заощзаджень та їх роль у повсякденному житті економічних суб 'єктів - домогосподарств, зв 'язок заощаджень з інвестуванням та роль інвестування у формуванні державної фінансової системи. Наведено приклад ефективного управління особистим бюджетом. Виявлено основні тендениї розвитку ощзадливості в Україні.

Ключові слова: ощуадливість, заощуадження, інвестування, бюджет.

The article considers the main components of frugality, the functions of savings and their role in the daily life of economic entities - households, savings and investment connection and role of investing in the formation of state financial system. An example of effective personal budget management is given. The main tendencies of frugality development in Ukraine are revealed.

Key words: Frugality, Savings, Investment, Budget.

У структурі фінансової грамотності населення, важливе місце посідає ощадливість. Основною метою економіки є задоволення безмежних потреб особистості за допомогою обмежених ресурсів. Саме ощадливість передбачає бережливе витрачання ресурсів, особливо фінансових. У сучасному світі людина завжди стоїть перед вибором витрачання своїх матеріально-фінансових ресурсів: «Чи витратити одразу все, або відкласти до кращих часів?». На такі роздуми їі спонукають як глобальні чинники, такі як економічний чи політичний стан країни, а також локальні, такі як: вдала реклама бажаного товару, непередбачувані випадки, сімейний стан, рівень доходу тощо. Однак сама ощадливість представляє більш складний економічний процес, від рівня якого залежить рівень фінансової грамотності населення. Ощадлива економічна поведінка економічного суб'єкту має на меті досягнення балансу між споживанням та заощадженням. 
Розділ III. Історичні та порівняльні аспекти в теорії і практиці духовно-інтелектуального виховання й навчання

Заощадження - це частина доходу, яка залишається після сплати усіх податків та необхідних споживчих витрат, і відкладається для подальшого використання. Заощадження виконують декілька функцій, а саме: 1) збільшення поточних витрат населення призводить до зменшення заощаджень та знижує їх довгострокову фінансову стійкість; 2) в основі заощаджень лежить добровільне відкладання грошових коштів із метою задоволення потреб, а саме: для забезпечення подальшого споживання, або отримання додаткового доходу; 3) заощадження - кошти призначення для накопичення можуть бути вкладені у різні види фінансових та нефінансових активів [1, с. 20-21]. Вкладення заощаджень домашніх господарств у фінансові та нефінансові активи має два ефекти.

Один із них, - це примноження у довгостроковому терміні своїх заощаджень завдяки відсоткам. Інший, — це працююча фінансова система. Інвестування домашніх господарств запобігає виникненню надлишку вільних грошей, який може призвести до зниження темпів виробництва та прискорення інфляційних процесів, що у свою чергу призводить до зниження заощаджень, оскільки домогосподарствам необхідно буде витрачати більше грошей на задоволення своїх невідкладних потреб.

Для ефективного управління частками особистого бюджету та визначення того, скільки грошей із доходу необхідно розподілити і яким чином, існують методи бюджетного розпорядження. Мета таких методів - створити фінансову «подушку» безпеки, яка дозволить забезпечити економічний суб'єкт достатньою кількістю фінансових ресурсів у випадок непередбачуваних обставин або фінансово забезпечити старість. Одним із таких методів є, запропонований Алексой Фон Тобель, «Метод 50-20-30». Його суть полягає у розподілі щомісячного доходу на три категорії: 1) 50 \% доходу витрачається на основні потреби, наприклад, житлово-комунальні послуги, їжу, ліки першої необхідності, тощо; 2) 20 \% повинні заощаджуватись та у подальшому інвестуватись; 3) 30 \% витрачається на особисті потреби. Такий сегментарний розділ доходів дозволяє задовольнити свої основні потреби, отримувати насолоду від життя та мати фінансово-забезпечене майбутне [3].

У розвитку ощадливості в Україні, як зазначають фахівці, існують такі тенденції, як-от: зміна макроекономічних умов у взаємозв'язку із 
схильністю населення до короткотермінового заощадження, коли гроші не інвестуються, а зберігаються у кишенях, «банках», гаманцях тощо; поява таких форм заощаджень як залишки на валютних рахунках та вклади у цінні папери; динамічне зростання заощаджень у іноземній валюті, яке пов'язане із зростаючою кількістю заробітчан; низький рівень заощаджень домашніх господарств у цінних паперах, пов'язаний із високою складністю доступу на ринок цінних паперів для домогосподарств; укладення домогосподарств у ліквідні матеріальні активи (квартири, дорогоцінні метали, антикваріат), які дозволяють зберегти заощадження від знецінення або одержати додатковий прибуток [2, с.5].

Виходячи з вищезазначеного, ощадливість громадян, котрі є економічними суб'єктами - домашніми господарствами, їх розумний підхід до заощадження коштів, уведення особистого бюджету та інвестування, дозволяє їм накопичувати велику частку загального приватного капіталу в межах держави, який дає стимул розвитку національної економіки, покращення її стану та загального економічного добробуту населення.

\section{Список використаних джерел:}

1. Коваленко В. В. Заощадження населення у забезпеченні фінансових ресурсів банків. Гроші, фінанси і кредит. 2019. Вип. 28. С. 275-283.

2. Котис Н. В. Місце і роль сектору домашніх господарств у суспільному відтворенні та економічному зростанні в Україні. Науковий журнал «Аспект». Донецьк: ООО «Цифровая Типография». 2014. № 3. С. 3-7

3. Alex von Tobel. Financially Fearless: The LearnVest Program For Taking Control Of Your Money. M.: Crown Business Publications, 2013. 366 s. 